\title{
Empirical Analysis of Internal Migration Influence on Development in Ghana From 1990 to 2012
}

\author{
Nicholas Awuse \\ Bolga Polytechnic \\ Tel: 233-203-192-445. E-mail: Akaare2002@yahoo.com \\ Patrick Tandoh-Offin \\ GIMPA \\ PO Box 122, 96101 Rovaniemi, Finland
}

Tel: 233-247-450-433. E-mail: ptandoh@gimpa.edu.gh

Received: October 5, 2013 Accepted: November 28, 2013 Published: February 11, 2014

doi:10.5296/jsss.v1i2.5098 URL: http://dx.doi.org/10.5296/jsss.v1i2.5098

\begin{abstract}
Using 800 questionnaire responses from seven regions (out of the ten regions in Ghana), this study determines how internal migration can be used to promote development in Ghana. One hundred questionnaires each was sent to three regions in the north and one hundred and twenty questionnaires to four metropolitan areas (Tamale, Accra, Kumasi and Sekondi/Takoradi). This was because these are migrants concentrated areas The data were collected by ten research assistants and twenty students from the three Universities, namely; University for the Development Studies, University of Education, Winneba and Technical Universities. The investigations show that there is a positive relationship between internal migration and socioeconomic development because the make available opportunities for access to immediate and flexible labour force. The study, therefore, recommends for policy makers to critically look at the state of internal migration in Ghana so as to institute policies that lessen the burdens of internal migrants. There is also the need to explore avenues for enhancing the resource capabilities of current migrants and their beneficiaries as a potential strategy to diversify their remunerative options in the long term.
\end{abstract}

Keywords: Internal Migration, Capability, Development 


\section{Introduction}

Internal migration, as compared to other forms of migration, has a superior prospect for generating socioeconomic development and contributing to economic growth in Ghana. This is due to the following benefits it can bring. In the first place, internal remittances in the form of smaller amounts can only reach many families in the rural areas in Ghana than international remittances which are huge but can get to only a few in urban communities. Internal migrants are likely to increase very fast because one does not need a visa, passport, invitation letters, statement of accounts as evidence before he/she travels. In addition, internal movements assumed to push people from poor background to places where there are many economic opportunities (relatively well developed regions than their counterparts).

Internal migration plays a significant role in pushing other sectors of the economy including agriculture, manufacturing, construction, coastal economies and services to grow. Migration experts have argued that the concept is not fully explored and that there is insufficient knowledge and understanding of the concept in Ghana. The study, therefore, argues that the benefits of internal migration need further explanation to explore its potentials fully in Ghana.

The times when migration only related to the movement of peoples away from violence for survival has been long replaced with a different meaning of migration, especially the kind that occurs in-country. The new motivation for migration is mostly purely economic survival and to prosper, to escape insecurity and poverty, and to move in answer to perceived opportunities. Migration is not a universal remedy for development problems (Tholen, 2005), but if properly managed, internal migration especially can deliver major benefits in terms of development. The balance and distribution of costs and benefits depends upon the nature of the migration in question, and on the links which migration establishes between places of origin and destination.

The probable benefits that internal movement of people had owing to occupation and financially viable opportunities is not of recent phenomena. On the other hand, there is convincing evidence from locations across the North and South divide in Ghana, and especially rural to urban that population mobility has increased at an extraordinary rate in the last two decades (North to Kumasi and between Kumasi, Accra, Takoradi, Sunyani and Tamale). What is especially striking is the increase in temporary and circular movements of people within regions in Ghana and include a spectrum of movements from trips that last several months, to daily commuting for work. The overall consequence is that while more people are moving permanently out of rural areas to urban areas, a growing number of people are also migrating provisionally or circulating between villages and other destinations (He, 2003).

Internal migration is important almost everywhere and in some countries, the phenomenon is far greater than international migration. It is estimated that in 2001, close to 120 million people were estimated to migrate internally in China, compared to the mere 458,000 people migrating internationally for work (Ping, 2003). In India too, internal migration numbers run into millions while international migration is only a fraction of this (Srivastava \& Sasikumar, 2003). There are references to the importance of internal labour migration and remittances in 
many other countries, including Bangladesh (Afsar, 2003); Pakistan (Gazdar, 2003); Cambodia (ADB, 2001), Vietnam (Anh et al., 2003; Government of Vietnam, 2003), Lao PDR (Acharya 2003), Mongolia (Tsogtsaikhan 2003), Ethiopia (RESAL 1999), Sub-Saharan Africa (Bryceson et al., 2003), Lesotho, Maldives and Papua New Guinea (Jerve, 2001).

In Ghana for example, about $40 \%$ of the total population move within the country, and out of these number, about $70 \%$ of migrants come mostly from the three northern regions (Northern, Upper East and Upper West) and the Volta region towards the cocoa growing and mineral deposits areas in the southern parts of the country. However, the remaining regions move within urban centers and outside the country for better living conditions. The basic problems the study seeks to find out include the following: is internal migration in Ghana a problem? Since it is the poorest, most desperate people, who migrate, how can we minimize it cost and maximize its benefits?

To this end, the paper has its overall objective to determine whether or not internal migration can influence development in Ghana. The paper also sought the following specific objectives:

- To create awareness among key stakeholders such as the government, legislature, and the general public of the potential development internal migration can bring.

- To scrutinize the nature of the relationship between internal migration and development.

- To recommend appropriate policies on how issues relating to internal migration might successfully and comprehensibly factor in development and poverty reduction objectives.

\section{Research Question}

Can Internal Migration Cause Socio-Economic Development in Ghana?

\section{A Review of Existing Literature}

\subsection{Internal Migration and Economic Development}

Migrant labour contributed massively to economic development through the kinds of subsectors described above but precise estimates on this contribution are not available. Based on data from Bangladesh, China, Vietnam and the Philippines, Anh (2003) concludes that migration is a driver of growth and an important route out of poverty with significant positive impacts on people's livelihoods and well-being. In the case of China, Murphy (2005) notes that migration has made major contributions to development, by accelerating economic growth, building up cities and establishing rural-urban linkages and return flows. Research by Chinese scholars estimates that labour migration from rural to urban areas contributed to $16 \%$ of total GDP growth in China over the past 18 years. They argue that migration has remained one of the key reasons that China has been able to sustain GDP growth rates above $8 \%$ over the past 25 years. A cheap and literate workforce has given China a competitive advantage relative to other countries. It has also been noted that migration has stimulated the transport sector. 


\subsection{Significance of Internal Migration}

It is generally assumed that educational accomplishment is known to be a major reason underlying the exclusion of the poor from the opportunities that come with economic growth and development (Ravallion \& Datt, 2002). There are also strong correlations between ethnic group, gender, and education. Building education and skills are therefore essential in helping poor and discriminated against people to break away from oppressive and low paying jobs.

A typical example from China is the Ministry of Agriculture initiative launched in 2003 of providing free vocational training for would be migrants or who are already in the cities (Ravallion \& Datt, 2002). The programme is now working well due to the combined efforts of NGOs, government and academics. Other tripartite partnerships have initiated migrant art projects aimed at building social capital among migrants and reducing urban public prejudice against them.

There are many factors that drive people to migrate, especially from the three northern regions and Volta region to the south and also from urban to urban. While some are common to several countries, such as regional inequality, under-employment in rural areas and the spread of labour intensive industries, other factors differ depending on the history, culture, policy environment and social structure of the country. Some of the main drivers of internal migration that appear to be common to Ghana today are discussed in order to draw the attention of policy makers to the magnitude and significance of the phenomenal increases in internal migration.

\subsection{Growth Determination and Growing Inequalities}

Ghana as a developing country is characterized by uneven development between the north and the south, as well as between some urban areas. Additionally, spatial inequalities are highly visible. The argument has been made that dramatic improvement in communications, services, construction, manufacturing and transport facilities has been a contributing factor that has created the conditions for the large-scale internal movement of people at unprecedented levels within Ghana (Balisacan \& Ducanes, 2005; Kanbur \& Venables, 2005).

The relationship between migration and inequality is two-way: inequality may drive migration and migration has also created a situation of inequality both within the sending area and between regions. We return to the latter issue under the impact of migration on poverty and inequality. Non-income inequalities related to, tribe, gender and ethnicity are also extremely important in shaping migration streams. In Ghana, inequalities related to income, ethnicity, gender and many others do not exist like some of the Asian Countries. High growth rates driven by labour-intensive production and services, labour-intensive manufacturing, construction and urban services are attracting large numbers of migrant workers from under-developed regions mostly in the north to the southern and other urban areas in Ghana.

\subsection{Construction, Processing and Manufacturing}

Construction activity in the cities as well as rural areas has been one of the most significant forces attracting labourers from the agricultural sector since the early 1980s. In Ghana, these 
are commonly found in Kumasi, Accra, Takoradi, and the mineral deposits towns (mining communities) and other urban areas. Majority of the active population in Ghana therefore tend to move to these regions and areas for perceived better economic opportunities.

Thus labour mobility in Ghana is greatest between the rural/agricultural regions and the urban informal labour markets. In addition, small rural industries employ significant numbers of landless and marginal paddy farmers for the past. It is known that most rural labourers pursue multiple income-earning activities combining a portfolio of farm and non-farm activities. In general, labour mobility is greatest between rural/agricultural regions and the urban informal labour markets. Again in Ghana, Cocoa growing areas, mining, robber plantation, oil and gas and many others attract most young Ghanaian migrants.

\subsection{High Effectiveness Agricultural Zones}

Rural-rural labour migration of poor people from marginal regions to more prosperous agricultural areas is widespread in Ghana with sharp regional differences in productivity and wages and low/moderate levels of mechanization. A case in point is the North which has one long dry season compared with the south which has two seasons, thus compelling people from the north and other similar areas in the country to move to the south especially Kumasi and other areas that have two seasons. There is some indication that a switch from rural-rural to rural-urban circular migration is occurring in areas where agricultural employment is shrinking and industrial jobs are being created either at the same destinations or elsewhere.

Again in Ghana, Cocoa growing areas, mining, robber plantation, oil and gas and many others attract most young Ghanaian migrants. A common feature across Ghana and other countries is that agriculture alone cannot sustain rural livelihoods. In Ghana, according to Statistical Service, 2010 report, agriculture employs $70 \%$ of the total labour force, yet she spends half of her foreign exchange to import rice and other cereals to Ghana. Female migration from the north to the southern cities in search for minor jobs is also on the increase, as they engaged in head porter jobs and other less-paid jobs. From the above, it was clearly established as to how related material world wide to the topic have been dealt with and we proceed to collect data as to how and why.

\section{Research Methodology}

The paper employs 800 questionnaires from the seven regions of Ghana. Questionnaires were sent out to 800 respondents in the selected regions: Greater Accra, Ashanti, Western, Brong Ahafo, and the three northern regions (Upper East, Upper West and Northern). These regions were chosen because they are either conducive for migrants or have push and pull factors. Of these numbers, one hundred questionnaires each were sent to each region with five districts chosen as a study area. It was only the Ashanti, Accra, Takoradi that had one hundred and twenty each because of the size of these areas. Ten research assistants were employed for the data collection which was purposive in nature. Although nationally representative data on internal remittances are lacking in Ghana, which hampers our understanding of the role of internal migration and development, there is mounting evidence through micro-studies as well as larger surveys that internal migration can subsidize inequality and contributes to 
overall economic growth and development. The methodology chapter was set to answer why and how the research was conducted. The results of the study have been presented as follows.

\section{Presentation, Results and Discussions}

\subsection{Remittance Services}

According to the respondents of this study, the technique of transferring money home can be risky and harmful business for migrants for the following reasons. First, migrants with low levels of education and few assets usually do not deal with formal banks and financial institutions. From the study, they rely on friends, family and other informal channels in Ghana to send money as compared with the hundi system in China to remit money. The common characters associated with this among others include theft, cheating and delays. They, therefore, suggested that governments need to devise a technique of assisting internal migrants to remit money easily without much difficulty. In Ghana, remittances sent home by internal migrants are used for various purposes including consumption, investments, education, health, food, agriculture and many others. In comparison with other studies globally, in China, the Ministry of Agriculture sample survey of 20,089 rural households estimated that, in 2004, the remittance contribution by migrant workers to rural household incomes was about to overtake earnings from agriculture (quoted in Harris 2004). These projections were made on the basis of the previous year's figures, where the 98 million or so rural out-migrants remitted roughly US $\$ 45$ billion (Rmb 370 billion), up $8.8 \%$ from the previous year. There are successful initiatives and experiments at the international level but financial channels within countries are still not suitable for migrant workers. One example related to internal remittances is the ICICI bank in India, which is currently conducting household surveys in several states with a view to developing financial services for poor migrant labourers. In Ghana, there is no formal system developed for migrants to send money home thus pushing them into informal ones.

\subsection{Building the Capacity of Migrants}

The study disclosed that many of these migrants do not possess the requisite skills to be formally employed in the formal sector but needs serious retraining in the informal sector to be gainfully employed.

It was then suggested that in order to create equal opportunities for migrants in Ghana, government need to introduce a programme such as the National Youth Employment Programme instituted in 2002 that created opportunities for the youth in Ghana, but lamented that the programme has been plagued with politics which prevented the programme from achieving the best results for skill migrants in Ghana.

According to the study, low educational attainment of migrants is common feature that underlying the exclusion of the poor from the opportunities that come with economic growth and there are strong correlations between gender and education. Building education and skills are important in helping poor and discriminated against people to break away from oppressive and low paying jobs. A classical example from China is the Ministry of Agriculture initiative launched in 2003 of providing free vocational training for rural people 
who are preparing to migrate or who are already in the cities. The programme is now working well due to the combined efforts of NGOs, government and academics. Other tripartite partnerships have initiated migrant art projects aimed at building social capital among migrants and reducing urban public prejudice against them.

\subsection{The Relationship between Internal Migration and Economic Development in Ghana}

From the study, it was evident that a number of children are now in schools because of the parents migration, better health care especially health insurance registration, improved food, clothing's, housing and improved investments in Ghana due to the efforts of migrants workers. This has established linkages between cities in the area of transportation and communication which has made life easy in Ghana according to the migrants. The study revealed that internal migrants in Ghana contribute about more than 50\% to Gross Domestic Product (GDP). In the study, Northern Ghana for example, has a migrant each in every household.

Findings from similar studies in other countries included data from Bangladesh, China, Vietnam and the Philippines Anh (2003) concludes that migration is a driver of growth and an important route out of poverty with significant positive impacts on people's livelihoods and well-being.

For instance, in China, Murphy (2005) comments that migration has made chief aid to development, by accelerating economic growth, building up cities and establishing rural-urban linkages and return flows. Research by Chinese scholars estimates that labour migration from rural to urban areas contributed to $16 \%$ of total GDP growth in China over the past 18 years. They argue that migration has remained one of the key reasons that China has been able to sustain GDP growth rates above $8 \%$ over the past 25 years. A cheap and literate workforce has given China a competitive advantage relative to other countries.

\subsection{Internal Migration Versus External Migration in Ghana}

It was established from the study that, in Ghana the internal migrants far outweighs the international migration for the following reasons: Internal migration is not so expensive, does not require visa, does not require invitation letters, need to have relative, or going to school or tour nor statement of accounts but international migrants do. It was rather surprising that internal migration is important almost everywhere and in Ghana is far greater than international migration. Ghana, Population and Housing Census 2010 also revealed similar pattern.

In other studies, close to 120 million people were estimated to migrate internally in China in 2001 against a mere 458,000 people migrating internationally for work (Ping, 2003). In Vietnam roughly 4.3 million people migrated internally in the five years before the 1999 census whereas the number of international migrants was fewer than 300,000 (Anh et al., 2003). In India too, internal migration numbers run into millions while international migration is only a fraction of this (Srivastava \& Sasikumar, 2003), there are references to the importance of internal labour migration and remittances in many other countries, including Bangladesh (Afsar, 2003); Pakistan (Gazdar, 2003); Cambodia (ADB, 2001), Vietnam (Anh 
et al., 2003; Government of Vietnam, 2003), Lao PDR (Acharya, 2003), Mongolia (Tsogtsaikhan, 2003), Ethiopia (RESAL, 1999), Sub-Saharan Africa (Bryceson et al., 2003), Lesotho, Maldives and Papua New Guinea (Jerve, 2001).

\subsection{The Way Forward for Internal Migration in Ghana}

From the study above, current development patterns and future projections on urbanization, the growth of manufacturing and agricultural development in Ghana, it is very likely that internal migration, both temporary and permanent, will persist and grow. There will be a transfer of populations from rural/agriculture to urban/non-farm areas and occupations but the rate at which this will occur is uncertain.

According to Population and Housing Census in Ghana 2010, there will be more migration of young adults into regions such as Ashanti, Greater Accra and Takoradi where this is likely to slow down, migration streams will also be affected. Circular migration is likely to continue and increase in Ghana where growth is likely to be limited to a few areas, employment is predominantly informal in the destination areas and where structural problems in the countryside continue to hamper access to capital and rapid poverty reduction. The introduction of social security for migrants in India; the reform of the Hukou system in China, the urban environment will become more welcoming and secure for migrants. This would speed up the transfer of populations from rural to urban areas and the transformation into more urbanized societies. The evidence reviewed so far shows that although a majority of poor migrant workers end up working in informal sector jobs, they may be able to exit poverty themselves and migration can contribute to development in both sending and receiving areas. Yet, migration continues to be viewed negatively by many people including policy makers in Ghana. Most governments have tried to control rural-urban movement through a combination of rural employment creation intervention programmes, anti-slum drives. Past and present governments continue to design policies and programmes that will discourage people to move especially to urban areas.

\section{Conclusion}

Policy makers need to recognise the importance of internal migration and development. As was revealed, internal migrants contribute more than 50\% to GDP growth of this country. Everything must be done to assist free flow of Ghanaians every where anyone wishes to move or migrate permanently or temporarily since resources distribution can never be evenly and the growth of private sector is not controlled by the government but demand and supply. Internal migration improves upon the lives of Ghanaians significantly and must be encouraged at all cost.

\section{Recommendations}

Ghana Government must do well to develop a better system for migrants to be sending their remittances such as the Hund system in China. This will help boast the migrants' image to work harder in order to get more money to remit than what is currently happening. As a follow up to this study, further research work can be done to ascertain what exactly should be done for migrants in Ghana. Official estimates can be published publicly for people to 
understand and appreciate the contribution migrants workers give to this country as well as official accommodation be given to internal migrants and tax taken.

\section{References}

Adger, W. N. (1999). Exploring Income Inequality in Rural, Coastal Viet Nam. Journal of Development Studies, 35(5), 96-119. http://dx.doi.org/10.1080/00220389908422593

Afsar, R. (2003). Dynamics of Poverty, Development and Population Mobility: The Bangladesh Case. Ad Hoc Expert Group Meeting on Migration and Development, Organized by the Economic and Social Commission for Asia and the Pacific, Bangkok, 27-29 August.

Anh, D. N. (2003). Migration and Poverty in Asia: With Reference to Bangladesh, China, the Philippines and Viet Nam. Ad Hoc Expert Group Meeting on Migration and Development, Organized by the Economic and Social Commission for Asia and the Pacific, Bangkok, 27-29 August.

Balisacan, A. M., \& Ducanes, G. M. (2005). Inequality in Asia: A Synthesis of Recent Research on the Levels, Trends, Effects and Determinants of Inequality in its Different Dimensions, The Inter-Regional Inequality Facility. London: Overseas Development Institute.

Black, R., Natali, C., \& Skinner, J. (2005). Migration and Inequality. Background Paper Prepared for the World Development Report 2006 on Equity \& Development.

Clawen, A. (2002). Female Labour Migration to Bangkok: Transforming Rural-Urban Interactions and Social Networks through Globalization. Asia-Pacific Population Journal, 17(3), 53-78.

Dayal, H., \& Karan, A. K. (2003). Labour Migration From Jharkhand. New Delhi: Institute for Human Development.

De Haan, A. (2005). Migration in The Development Studies Literature: Has it Come Out of Marginality? paper for UNU-WIDER Jubilee Conference, Future of Development Economics, June.

Deshingkar, P. (2005). Temporary Internal Migration and Development in India. Paper Presented at IOM-SSRC_ESRC Workshop on Migration and Development Within and Across Borders.

Deshingkar, P., \& Start, D. (2003). Seasonal Migration for Livelihoods, Coping, Accumulation and Exclusion. Working Paper No 220, London: Overseas Development Institute.

Deshingkar, P., Winkels, A., Chien, T. T., Shaheen, A., \& Thuy, N. D. (2004). The Quality of Life of Migrants in Vietnam. Paper Commissioned by UNFPA, Vietnam.

Djamba, Y., Goldstein, A., \& Goldstein, S. (1999). Permanent and Temporary Migration in Viet Nam During a Period of Economic Change. Asia-Pacific Population Journal, 14(3), $25-48$. 
General Statistics Office. (2005). The 2004 Migration Survey: Major Findings, Hanoi, Vietnam: Statistical Publishing House.

Godfrey, M., Sovannarith, S., Saravy, T., Dorina, P., Katz, C., Acharya, S., ... Thoraxy, H. (2001). A Study of the Cambodian Labour Market: Reference to Poverty Reduction, Growth and Adjustment to Crisis, Phnom Penh, Cambodia: Development Analysis Network.

Government of India. (2005). Data Highlights - Table D1, D2 \& D3 Census of India 2001, GoI.

Guest, P. (1998). The Dynamics of Internal Migration in Vietnam, UNDP Discussion Paper 1, Hanoi, Vietnam.

Guest, P. (2003). Bridging The Gap: Internal Migration in Asia. Population Council Thailand, Paper Prepared for the Conference on African Migration in Comparative Perspective, Johannesburg, South Africa, 4-7 June.

Haberfeld, Y., Menaria, R. K., Sahoo, B. B., \& Vyas, R. N. (1999). Seasonal Migration of Rural Labour in India. Population Research and Policy Review, 18(6), 471-487. http://dx.doi.org/10.1023/A:1006363628308

He, X. F. (2003). Regulating Rural-Urban Migrants in Beijing: Institutional Conflict and Ineffective Campaigns. Journal of International Law, 177.

IIED. (2004). Stay on the Farm, Weave in the Village, Leave the Home. Livelihood Diversification and Rural-Urban Linkages in Vietnam's Red River Delta and Their Policy Implications, Briefing Paper 9, London: International Institute for Environment and Development.

ILO. (2004). Migration: Opportunities and Challenges for Poverty Reduction, Technical Briefing Note No 11, 'Working Out of Poverty', Jakarta, Indonesia.

Jha, V. (2005). Migration of Orissa's Tribal Women: A New Story of Exploitation. Economic and Political Weekly, Commentary, 9 April.

Kanbur, R., \& Venables, A. J. (2005). Spatial Inequality and Development Overview of UNUWIDER Project.

Karan, A. (2003). Changing Patterns of Migration from Rural Bihar. In G. Iyer (Ed.) Migrant Labour and Human Rights in India (pp. 102-39), New Delhi: Kanishka Publishers.

Leones, J. P., \& Feldman, S. (1998). Nonfarm Activity and Rural Household Income: Evidence from Philippine Microdata. Economic Development and Cultural Change, 46(4), 789-806. http://dx.doi.org/10.1086/452374

Mosse, D. (2002). Brokered Livelihoods: Debt, Labour Migration and Development in Tribal Western India. Journal of Development Studies, 38(5), 59-87. http://dx.doi.org/10.1080/00220380412331322511

Mosse, D., Gupta, S., Mehta, M., Shah, V., \& Rees, J. (1997). Seasonal Labour Migration in 
Tribal (Bhil) Western India, Report to DFID-India, New Delhi KRIBP Working Paper, Swansea: Centre for Development Studies, University of Wales.

Munir, H. M. R. (2002). Population and Development in Indonesia. http://dx.doi.org/10.1017/CBO9780511550003

Murphy, R. (2005). Migration in China. background note prepared for the Asia 2015 migration paper.

Murphy, R. (2002). How Migrant Labour is Changing Rural China, Cambridge: Cambridge University Press.

Naylor, R. (2006). The Rural Labor Market in Indonesia. In S. Pearson (Ed.) Indonesian Rice Policy, Ithaca: Cornell University Press. Retrieved from www.stanford.edu/group/FRI/indonesia/documents/ricebook/Output/chap5.html

Olsen, W. K., \& Ramana, M. R. V. (2000). Contract Labour and Bondage in Andhra Pradesh (India). Journal of Social and Political Thought, 1(2).

Osaki, K. (2003). Migrant Remittances in Thailand: Economic Necessities or Social Norm? Journal of Population Research, 20(2), 203-222. http://dx.doi.org/10.1007/BF03031852

Olsen, W. K., \& Ramanamurthy, R. V. (2000). Contract Labour and Bondage in Andhra Pradesh (India). Journal of Social and Political Thought, 1(2).

Osaki, K. (2003). Migrant Remittances in Thailand: Economic Necessities or Social Norm?' Journal of Population Research, 20(2), 203-22. http://dx.doi.org/10.1007/BF03031852

Osaki, K. (1999). Economic Interactions of Migrants and Their Households of Origin: Are Women More Reliable Supporters. Asia Pacific Migration Journal, 8(4), 447-71.

Pasuk, P., \& Isra, S. (2000). Globalization and Inequality: The Case of Thailand. paper prepared for OECD conference on Poverty and Inequality in Developing Countries, Paris, 30 November-1 December.

Ravallion, M., \& Datt, G. (2003). Is India's Economic Growth Leaving the Poor Behind? World Bank Policy Research Working Paper No 2846, Washington, DC: World Bank.

Rodriguez, E. R. (1998). International Migration and Income Distribution in the Philippines. Economic Development and Cultural Change, 46(2), 329-50. http://dx.doi.org/10.1086/452341

Rogaly, B., Biswas, J., Daniel, C., Abdur, R., Kumar, R., \& Sengupta, A. (2001). Seasonal Migration, Social Change and Migrants Rights, Lessons from West Bengal. Economic and Political Weekly, 36(49), 4547-58.

Rogaly, B., Coppard, D., Ratique, A., Rana, K., Sengupta, A., \& Biswas, J. (2002). Seasonal Migration and Welfare/Illfare in Eastern India: A Social Analysis. Journal of Development Studies, 38(5), 89-114. http://dx.doi.org/10.1080/00220380412331322521

Song, L. (2004). East Asian Experience: China. mimeo, Canberra: Australian National 
University.

Srivastava, R. (2005). India Internal Migration Links with Poverty and Development country paper regional conference on Migration and Development in Asia, Lanzhou, China, 14-16 March 2005.

Tholen, B. (2005). The Europeanisation of Migration Policy: The Normative Issues. European Journal of Migration and Law, 6(4), 323-35. http://dx.doi.org/10.1163/1571816044088827

UNDP. (1995). Environment and Natural Resource Management. Strategy and Action Plan for UNDP Vietnam (2nd ed.)

UNDP. (2004). Migrant Labour - Problems of the Invisible, Chapter 8 in Punjab Human Development Report, New York: United Nations Development Program.

Wandschneider, L., \& Mishara, P. (2003). The Role of Small Rural Towns in Bolanair District, India: A village-level Perspective, Natural Resources Institute Report No 2750, DFID-World Bank Collaborative Research Project on the Rural Non-farm Economy and Livelihood Enhancement.

\section{Copyright Disclaimer}

Copyright reserved by the author(s).

This article is an open-access article distributed under the terms and conditions of the Creative Commons Attribution license (http://creativecommons.org/licenses/by/3.0/). 